\title{
THE IMPaCt Of Social Media ON ACADEMIC Performance Of Selected College Students
}

\author{
Gilbert M. Talaue ${ }^{1}$, Ali AlSaad ${ }^{2}$, Naif AlRushaidan ${ }^{3}$, Alwaleed AlHugail $^{4}$, \\ Saad AlFahhad ${ }^{5}$ \\ ${ }^{1}$ Assistant Professor, ${ }^{2,3}$ Business Administration Student-Researcher, ${ }^{4,5}$ Management \\ Information System Student-Researcher \\ Business Administration Department, Jubail University College, Jubail Industrial City, \\ Kingdom of Saudi Arabia
}

\begin{abstract}
The purpose of this article is to assess the impact of social media on academic performance of selected college students. In this article, the authors raise the actual impact of daily communication of youth in social media. Descriptive research design was utilized to gain accurate profile of situation. Sixty (60) Business Administration and Management Information System students who are actively using social media are the respondents of the study. It was conducted during the summer semester of academic year 20172018.Summing-up, social networks becomes an integral part of the students' full life, took up most of their free time.Undoubtedly, in social networks, there are also things useful for the development of the students. In addition, communication with peers through social networks can help a student socialize, find new friends, discuss with them issues related to studies. Thus, it can be concluded that social media have a dual impact on student achievement, and it is necessary to approach adolescents' use of social networks with ultimate responsibility.
\end{abstract}

\section{KEYWORDS}

social network, social media,Saudi Arabia, impact of electronic technology, social media effect

\section{INTRODUCTION}

Today the Internet has taken a firm place in people's lives. It is difficult to imagine a young man who at least once a day did not check for updates in social networks and did not leaf through the news lines. The modern reality requires us to stay in touch and keep abreast of the latest news and trends. However, does this trend affect the performance of students?

When social media such as Facebook, YouTube and Twitter appeared, our world was divided into online and offline. Social media are online technology platforms that help to connect people together far and near. It is used to build relationship among people [18]. With their help, we can communicate with each other, even on different continents, listen to music, read books, look at photos and much more. Social media have greatly simplified our lives and tightly tied to ourselves [17].

During the time spent discovering individuals for acquaintances, youngsters go into different connections and get the chance to speak with a relatively boundless number of individuals and premium gatherings, with a wide range of identities, take in a considerable measure of stories, have the opportunity to trade suppositions and talk about issues important to them. Therefore, users of social networks, in most cases, are a representative of the younger generation. 
International Journal of Advanced Information Technology (IJAIT) Vol. 8, No.4/5, October 2018

According to scientists, social networks are especially dangerous for teenagers, as they form a false impression that love and friendship are easy to conquer and just as easy to destroy [5]. In addition, young people who are acquainted with the fast stream of Internet life, the truth may appear to be excessively dull, and they can have a go at, making it impossible to "restore" it by making imprudent activities.Some are supporters of the use of social media. They claim that the latter provide access to knowledge and help students exchange information quickly. Others think that students' use social media primarily to communicate about everything except studies and that they only distract students from the learning process. The use of social media by students helps to have access to basic information as quick as possible [18].

Many universities and schools around the world restrict the access to social networks within its buildings. They justify this by helping students concentrate on their studies. On the other hand, they deny students the opportunity to use the numerous materials available on these resources, such as scientific videos on YouTube[8].

The setting of study is the one of the college in eastern province of Saudi Arabia, the Jubail University College (JUC). JUC is an affiliate of the Royal Commission for Jubail\& Yanbu. It was established in 2006 to achieve the objectives of the Royal Commission, in developing human resources and to provide the Saudi manpower with high education and training so that they can properly manage the Kingdoms' growing economy in its various sectors [7]. The aim of this study is to find out the impact of social media on academic performance of selected college students. To achieve this, existing studies will be analyzed, as well as survey among respondents will be conducted. Respondents are the sixty (60) students who are actively using social media.

\subsection{Concepts And Literature RevieW}

To shed light on the positive and negative sides of using social media in general, as well as discover its effects on students' academic performance, existing studies were reviewed.

Studies found out that academic outcome of students who spent most of their time interacting using social media are positive because they were able to share and generate ideas and concepts related to their studies. They also use these sites for having fun as these social media sites are helpful in their academic work [3].

A similar study revealed that online social media had improved the communication between the faculty member and students which facilitate the communication of the correct information and improve understanding and the development of the ideas and the courses. Based on the information collected, it is noticeable to say that the use of the social media during the lecture time is not recommended [1].

Mensah \&Nizam[10]concluded in their study that social media platforms has a significant impact on students' academic performance in Malaysia tertiary institutions. Nevertheless, among the six variables used in their study, time appropriateness and health addiction has a stronger significant influence on students' academic performance. This is because time management plays an essential role in determining the success and failure of an individual. Thus students who lack time management can easily fall prey to the negative impact of social media. Likewise, health and addiction, students who are engrossed with social media platforms ends up skipping meals which has health impact.

According to the study of Owusu-Acheaw\& Larson [12], it was revealed that the use of social media had affected the academic performance of their respondents negatively and further 
International Journal of Advanced Information Technology (IJAIT) Vol. 8, No.4/5, October 2018

confirmed that there was a strong positive relationship between the use of social media and academic performance. Their study further revealed that most of their respondents use social media sites to chat rather than for academic purpose.

Based on the study of Alwagait, Shazad and Alim[2], it was found that social media usage on weekly basis displayed a positive skew where most students do not use social media excessively. Respondents in their study felt that time management and football were factors that contributed towards negative academic performance besides excessive social media use.

Study in Kogi State University found out that the exposure of the students to social media have effect on their academic performance. Evident show that social media have negative influence on the academic performance of students. Students who spend more time on social media are likely to perform poorly in their academics this is because instead of reading books, thy spend time chatting and making friends via social media and this will definitely have negative effect on their academic performance [4].

Another study shows that students are not only affected by social media, employees and employers too. A U.K. firm released a study showing that people who use Facebook, Twitter and other social networks while at work extracts a heavy cost on their employers [14].

According to Kolan and Dzadza[8], the nature of social media as a useful servant but a dangerous master and a two-edge sword has been revealed in the findings of the study. Despite the benefits that students can harness from social media networks such as sharing of information, building relationship, partaking in group discussion, there is to some extent addiction and distraction of attention caused by the use of social media which could have serious consequences on the academic life of students.One of the negative effect of social media is piracy. The primary motivator for Australians of all ages illegally downloading movies and TV shows is that it is free 13].

According to Landry [9], social media a tool that could be used for good or bad, it all depends on the person. Social media has its layers of good and bad.Yes, it is easier to remember the bad rather than the good but, social media sites have created opportunities for people all over the world

\subsection{Conceptual Paradigm}

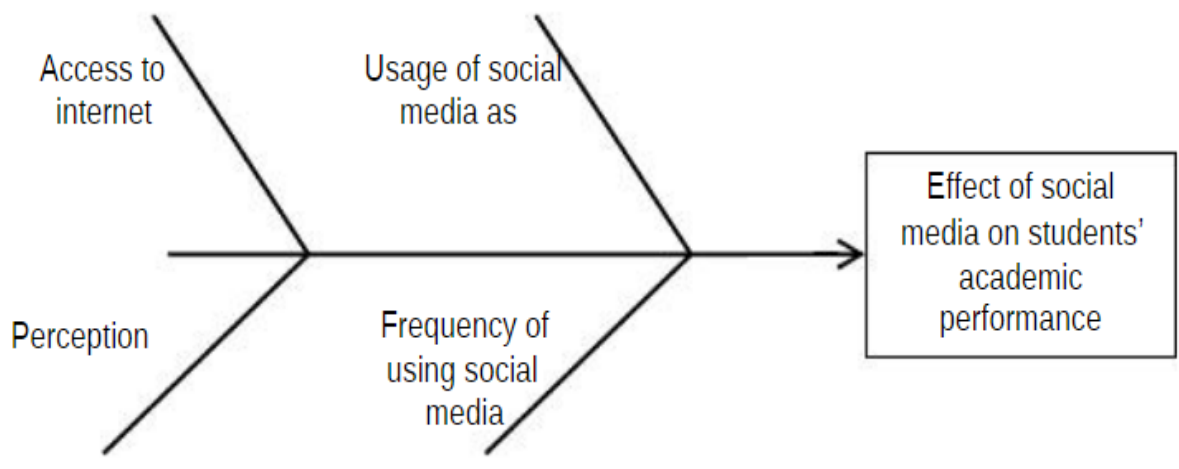

Figure 1: Paradigm of the study 
International Journal of Advanced Information Technology (IJAIT) Vol. 8, No.4/5, October 2018

The paradigm of this study adopted the Shikawamodel, also known as fishbone diagram. Skikawa model is causal diagram developed by Kaoru Ishikawa that shows the causes of a specific event [19]. Thevariables of social media that may affect the students' academic performance are: access to internet; usage of social media; their perception on social media; and their frequency of using it. With these variables, the present study will identify the impact of using social media to the academic performance of the respondents and will be able to draw recommendations that may improve the learning process and reduce the negative impact of social media.

\subsection{Statement Of The Problem}

This paper aims to find out the positive and negative impact of social media on students' academic performance. Specifically it sought to answer the following:

1. What is social media and why students use it?

2. How much time do students spend using social media?

3. What is the impact of social media on students' academic performance?

\subsection{ASSUMPTIONS}

The present study that will assess the effect of social media on students' academic performance presupposes the following:

1. Students use social media to communicate and study.

2. On average, students spend at least on hour a day for social media use.

3. The impact of social media on academic performance could be positive or negative at the same time.

\subsection{SCOPE AND DELimitation}

The study was conducted to assess the impact of social media on students' academic performance. Sixty (60) students who are actively using social media are the respondents of the study. It was conducted during the summer semester of academic year 2017-2018.

The study limited only on variables of social media that the researchers assumedthat has effects of respondents' academic performance. These variables are respondents'access to internet, usage, perception on social media, and their frequency of using it.

\subsection{Significance OF The STUdy}

Social networks are becoming more popular among university students and are a new way of spending free time and serve as a separate channel for finding the necessary information, both educational and entertaining. Therefore, it is urgent to examine the question of what effect social networks have on their users, in particular, how the use of social networks affects the academic success of students. This study will discover this information, giving the researchers an opportunity to explore and gain new knowledge. Furthermore, it can be used for future studies.

\section{Methodology}

This part presents the methodology used. Discussed here are research design, the sources of data that includes the locale of the study and research population, instrumentation and data collection, and tools used for data analysis. 
International Journal of Advanced Information Technology (IJAIT) Vol. 8, No.4/5, October 2018

\subsection{ReSEARCh DeSign, SourCes Of DATA, InSTRumentation And Data Collection, And Tools For Data Analysis}

The study used the quantitative as well as qualitative methods of research. Descriptive research design was utilized to gain accurate profile of situation [16].

To support the study, information relevant to the study were obtained from both primary and secondary data. Primary data were acquired from the respondents of the study, sixty student respondents. On other hand, secondary data were obtained from previous studies, literatures, books, documents, and electronic materials related to the current study.

The instrument for data collection was the survey questionnaire, observations, review of previous studies and analysis. To gather data for the three research questions, survey, review of literatures and analysis were used. Survey questionnaires were floated to the respondents. It is a tool containing several questions to gather information from the respondents. The survey questionnaire contains clear and simple questions that enable the respondents to provide accurate information. Each item in the survey questionnaires are intended to answer the research subproblems. Google Formwas used to create the questionnaire for the respondents. Google Forms are amazing tool that is free and powerful, it is ideal for anyone who needs to gather information about almost anything. Google Forms is buried within Google Drive right beneath the word processor, spreadsheet and presentation apps [21].

The data that were gathered were collected, tallied and tabulated. These data were presented in graphs were analyzed and interpreted for the readers to understand better the results obtained.

To determine the appropriate sample size, Slovin's formula was used [6]. There are 71 students actively using social media that are members of department's WhatsApp group. Slovin's formula is written as:

$$
\begin{array}{ll}
\text { Where: } & \mathrm{n}=\mathrm{N} /\left(1+\mathrm{N}^{2}\right) \\
& \mathrm{n}=\text { number of samples } \\
& \mathrm{N}=\text { total population } \\
& \mathrm{e}=\text { error tolerance }(0.05) \\
\text { thus, } & \\
& \mathrm{n}=\mathrm{N} /\left(1+\mathrm{N} \mathrm{e}^{2}\right) \\
& =71 /\left(1+\left(71 \mathrm{x}\left((0.05)^{2}\right)\right)\right. \\
& =71 / 1.1775 \\
& =60.3 \text { or } \mathbf{6 0}
\end{array}
$$

To answer the three research questions, statistical tools were identified. For first and second research question, aside from literature review, mode was used. For the third research questions, average weighted mean was utilized.

The collected data were used to analyze the impact of social media on students' academic performance.

\section{Presentation, Analysis And Interpretation Of Data}

This section presents the data gathered, the analysis and their interpretation relative to the questions raised in the study. The respondents' responses are evaluated against the following parameters: 
International Journal of Advanced Information Technology (IJAIT) Vol. 8, No.4/5, October 2018

\subsection{The Social Media And Why Students Use It}

Social media is the collective of online communications channels dedicated to community-based input, interaction, content-sharing and collaboration. Websites and applications dedicated to forums, microblogging, social networking, social bookmarking, social curation, and wikis are among the different types of social media.Some prominent examples of social media are facebook, twitter, google+, Wikipedia, linkedin, Reddit, and penterest [15].

The use of social media in education provides students with the ability to get more useful information, to connect with learning groups and other educational systems that make education convenient. Social network tools afford students and institutions with multiple opportunities to improve learning method [20].

In school, the use of online platforms such as school website will give students the right access to quality information about the school environment, departments, faculties, rules, and regulations. It has been observed that social media has a wider and faster means of circulating information not only to the students of an institution but also to the generality of the public [18].

To address the issue on why students are using social media, the researchers floated questionnaires to the respondents (refer to appendix). Item number 1,2,4,5, and 6, gave answer to this matter. Fifty-six $(93 \%)$ of the respondents has free access to the internet, only four $(6.7 \%)$ don't have free access to the internet. Almost everyone can freely access the internet with their smartphone anytime.

When it comes to usage of social media, twenty-one (35\%) of the respondents said that they are using it for communication; eighteen (29.5\%) claimed that they are using it to watch movies and listen to music; fifteen (25.5\%) are using it to find information for educational purposes; and only six $(10 \%)$ for online games. It turned-out that respondents' main purpose is for communication. Aside from communication, study revealed that respondents are using internet and social media for learning. In the course of the study, it was found that forty-three $(71.7 \%)$ do theirassignments using the internet; twelve (20\%) preferred the traditional way of going to library and read books for the assignment; and five (8.3\%) answered that they neither use social media or library to do their assignments. As we can notice, most students do not need libraries and books to do their assignments, since internet is available.

Since English is not the native language of the respondents, but English is the medium of instruction at the university, the researchers asked the respondents if they are using their smartphones during class to grasp some English vocabulary. Twenty-nine (48.3\%) answered "always"; twenty-three (38.3\%) claimed sometimes; and eight (13.3\%) arenot using phone during classes. In most cases, students use their phone during the classes.

\subsection{Time Students Spend In Social Media}

According to news agency Newspoll[11], 99\% of teenagers aged 16 to 17 years use social networks and 78 percent of children aged 8-9visit sites like Facebook, young people spend up to 7 hours a day in them. Truth be told, a huge number of individuals today don't speak to their lives without every day visits to interpersonal organizations, draw data from the news sources of Internet destinations, convey through remarks from different networks, and so forth.

For the number of hours spend by respondents on social media, item number 3 of the survey questionnaire addressed this. The frequency of internet users spend on average 4-6 hours per day 
International Journal of Advanced Information Technology (IJAIT) Vol. 8, No.4/5, October 2018

in social media is twenty-three (38.3\%); seventeen (28.3\%) spend $1-3$ hours; sixteen $(26.7 \%)$ spend more than 6 hours on internet for social media; and four $(6.7 \%)$ are not sure how much time they spend on internet for social media.Overall, the largest part of the respondents use social media 4-6 hours per day.

\subsection{Impact Of Social Media On Students’'Academic Performance}

According to the results of the survey, it was found out that twenty-three (38.3\%) strongly agreed that social media has negative effect on their academic performance. It was revealed on interview with the respondents that sometimes they don't have time to make assignment or study because they had long been on social media; seventeen $(28.3 \%)$ did not face such problem; twelve $(20 \%)$ answered neutral; and eight (13.3\%) revealed that they don't encounter any problem due to social media usage.

In terms of positive effect of social media, respondents revealed the following: ten (16.7\%) strongly agree of the positive effect; thirty-six $(60 \%)$ agreed; thirteen $(21.7 \%)$ claimed that it neutral neither positive nor negative; and one (1.7\%) disagree of the positive effect.

Summing up, it turned out that the internet occupies a specific place in the life of student respondents. Majorityof the respondents cannot leave their phone even during the class session. Majority of them performs homework through the internet, watch the series every day, but it does not interfere with their educational process.

\section{FINDINGS}

The primary motives for using social networks for them are the search for friends, classmates and communication with them. The time spent on informal organizations enables most respondents to compose their own particular relaxation time, and in addition get ready for exams.Most students spend around $20 \%$ of their time using social media.

Almost half of those surveyed admit that using the social network helped them in their personal lives and communicating with friends, organizing leisure and in search of interest groups, some argue that social networks did not affect their way of life in any way, and only a few acknowledged that social networks had influenced on their free time, $10 \%$ caused addiction.

Summing up, it should be noted that social networks, becoming an integral part of the students' full life, took up most of their free time. Having superseded the methods for correspondence, they replaced the understudies' leisure activities and verbal correspondence. The informal organization, and not the course book and the instructor, moved toward becoming for them the main colleague in anticipation of exams.

Often the student does not have time to absorb the information received in the lessons. After all, in the phone or tablet screen, there are things much more interesting - correspondence with peers, news tapes, all kinds of social networks, and, of course, YouTube videos. Also, all the free time a student can spend on the Internet. Instead of doing sports, reading a book, chatting with their peers "live," preparing for lessons or just walking, he will spend time on social networks. Of course, this negatively affects their physical and intellectual development.

Undoubtedly, in social networks, there are also things useful for the development of the student a lot of educational groups on Facebook and educational videos from YouTube. In addition, communication with peers through social networks can help a student socialize, find new friends, discuss with them issues related to studies. In addition, in social networks, a child can relax for a while and get distracted from the everyday college routine. 
International Journal of Advanced Information Technology (IJAIT) Vol. 8, No.4/5, October 2018

\section{COnClusion, Recommendation And Direction For Future RESEARCH}

Based on the findings, social media becomes an integral part of the student's full life, took up most of his spare time. The time spend by the respondents on social media stressed that the impact on their academic performance ends up negative.

So, the social media, which also has a familiar name as a social networks or web, chooses students as its potential victims. All kinds of computer technologies, mobile phones have significantly expanded the scope of both positive and negative factors of the spiritual and intellectual development of the younger generation.

Thus, it can be concluded that social media have a dual impact on student achievement, and it is necessary to approach adolescents' use of social networks with ultimate responsibility. In no case should we forget about the negative consequences that excessive social infatuation could have.

Based on the finding and conclusions drawn, the following recommendations are hereby offered: Institutions should focus on making pleasant things useful - promoting social networks as a tool not only for communication and entertainment but also for learning.

Social networks should allow their users to voluntarily restrict attendance on certain days, for example, to students during a session.

Finally, students themselves must realize all the potential harm from excessive use of social networks, and responsibly approach the learning process and academic results.

\section{References}

[1] Abousaber, I., Oueder, M. (2018). A Study on the Impact of Social Media Usage on Student Academic Performance: University of Tabuk an Example. American Scientific Research Journal for Engineering, Technology, and Sciences (ASJETS), 40(1), pp. 77-88

[2] Alwagait, E., Shahzad, B. (2014). Impact of social media usage on students' academic performance in Saudi Arabia, Computers in Human Behavior, http://dx.doi.org/10/1016/j.chb.2014.09.028

[3] Amin, Z., Mansoor, A,.et.al (2016).Impact of Social Media of Student's Academic Performance.International Journal Business and Management Invention, 5(4), pp. 22-29

[4] Asemah, S., Okpanachi, R. (2013). Influence of social media on the academic performance of the undergraduate students of Kogi State University, Anyigba, Nigeria, Research on Humanities and Social Sciences, 3(12), pp. 90-96

[5] East, S. (2016). Teens: This is how social media affects your brain. CNN.Retrieved from https://edition.cnn.com/2016/07/12/health/social-media-brain/index.html.

[6] Ellen, S. (2017). Slovin's Formula Sampling Techniques. Sciencing. Retrieved from https://sciencing.com/slovins-formula-sampling-techniques-5475547.html

[7] Jubail University College (2018).About Jubail University College. Retrieved on 20/2/2018 from http://www.ucj.edu.sa/en/about/Pages/About-Jubail-University-College.aspx

[8] Kolan, B., Dzandza, P. (2018). Effect of social media on academic performance of students in Ghanian Universities: A case study of University of Ghana, Legon, Library Philosophy and Practice (e-journal), https://digitalcommons.unl.edu/libphilprac/1637

[9] Landry, T. (2014). How Social Media Has Changed Us: The Good and The Bad. Retrieved from https://returnonnow.com/2014/09/how-social-media-has-changed-us-the-good-and-the-bad/

[10] Mensah, S., Nizam I. (2016). The impact of social media on students' academic performance - a case of Malaysia Tertiary Institution. International Journal of Education, Learning and Training, 1(1), pp. $14-21$ 
International Journal of Advanced Information Technology (IJAIT) Vol. 8, No.4/5, October 2018

[11] Newspoll. (2013). Like, Post, Share Young Australians' Experience of Social Media. Australian Communications And Media Authority. Retrieved from https://www.acma.gov.au//media/mediacomms/Report/pdf/Like-post-share-Young-Australians-experience-of-social-mediaQuantitative-research-report.pdf?la=en.

[12] Owusu-Acheaw, M., Larson, A. (2015). Use of social media and its impact on academic performance of tertiary institution students: A study of students of Koforidua Polytechnic, Ghana, Journal of Education and Practice, 6(6), pp. 94-101

[13] Research into the online behaviour and attitudes of Australians in relation to movie and TV piracy (2013). Intellectual Property Awareness Foundation. Retrieved from https://www.aph.gov.au/DocumentStore.ashx?id=1bff7481-b92a-4bc7-a2e7

[14] Reuters. (2009). Study: Facebook, Twitter Use At Work Costs Big Bucks.Retrieved from https://www.reuters.com/article/urnidgns852573c4006938800025765b00619aidUS399557440920091026.

[15] Rouse, M. (n.d.). Social Media. WhatIS.com. Retrieved from https://whatis.techtarget.com/definition/social-media

[16] Saunders, M., Lewis, P., Thornhill, A. (2012). Research Methods for Business Students. Pearson, UK.

[17] Shensa, A., Sidani, J., Lin, L., Bowman, N., \&Primack, B. (2015). Social Media Use and Perceived Emotional Support Among US Young Adults. Journal Of Community Health, 41(3), 541-549. doi: 10.1007/s10900-015-0128-8.

[18] Social Media by Students (2017). BlogDashConten creation by bloggers. Retrieved from http://blog.blogdash.com/media-industry/positive-negative-use-social-media-students/

[19] Talaue, G. M. (2018). Practical Basic Research Writing Manual for College Students. Lambert Academic Publishing, Germany

[20] The Role of Social Media in Education (2017). London College of International Business Studies. Retrieved from https://lcibs.co.uk/the-role-of-social-media-in-education/

[21] Wolber, A. (2014). Use Google Forms to create a survey. Retrieved from https://www.techrepublic.com/blog/google-in-the-enterprise/use-google-forms-to-create-a-survey/

\section{AUTHORS}

Gilbert M. Talaue holds doctorate degree in Business Administration. He is currently working as Assistant Professor of Business Administration at Jubail University College, Jubail Industrial City, Kingdom of Saudi Arabia

Ali AISaad is currently taking-up Bachelor of Science in Business Administration at Jubail University College, Jubail Industrial City, Kingdom of Saudi Arabia

NaifAIRushaidanis currently taking-up Bachelor of Science in Business Administration at Jubail University College, Jubail Industrial City, Kingdom of Saudi Arabia

Alwaleed AlHugailis currently taking-up Bachelor of Science in Management Information System at Jubail University College, Jubail Industrial City, Kingdom of Saudi Arabia

SaadAlFahhad is currently taking-up Bachelor of Science in Management Information System at Jubail University College, Jubail Industrial City, Kingdom of Saudi Arabia 